\title{
Performances of Improved Lablab Varieties for Their Agronomic Characteristics and Chemical Compositions in Adola Sub-site of Bore Agricultural Research Center
}

\author{
Teshale Jabessa ${ }^{*}$, Zinash Amare, Genet Dejene \\ Oromia Agricultural Research Institute (IQQO), Bore Agricultural Research Center (BOARC), Bore, Ethiopia \\ Email address: \\ teshalejabessa@gmail.com (T. Jabessa) \\ ${ }^{*}$ Corresponding author

\section{To cite this article:} \\ Teshale Jabessa, Zinash Amare, Genet Dejene. Performances of Improved Lablab Varieties for Their Agronomic Characteristics and \\ Chemical Compositions in Adola Sub-site of Bore Agricultural Research Center. Advances in Biochemistry. Vol. 9, No. 2, 2021, pp. $25-28$. \\ doi: 10.11648/j.ab.20210902.12
}

Received: February 8, 2021; Accepted: June 2, 2021; Published: June 7, 2021

\begin{abstract}
A study was conducted with the objective to identify adaptable and chemical composition of Lablab varieties. Three Lablab Beresa-17, Gabis-55 and Local variety +were tested in randomized complete block design (RCBD) with three replications. The result revealed that date of maturity was significantly $(\mathrm{p}<0.05)$ differ between the tested treatments. Among the tested varieties Gabis-55 was took longer day (144 days) while, the local varieties required the short (129.2 days) to reach for seed maturity. Fresh biomass yield, seed yield, plant height, pod per plant and pod length were not significantly ( $>0.05$ ) differ among the tested varieties. The analyzed chemical compositions indicated, Beresa-17 variety had the highest in Organic matter (OM), crude protein (CP), neutral detergent fiber (NDF) and dry matter (DM) and less in acid detergent fiber (ADF), acid detergent lignin (ADL), and total ash content (TASH) content while, Gabis-55 was highest in acid detergent lignin (ADL) and acid detergent fiber (ADF) and less in crude protein (CP) content. The local variety had the highest in neutral detergent fiber (NDF) and total ash content (TASH) and less in dry matter (DM) content than the rest varieties. The result of this study implied that Gabis-55 variety was adapted and being productive regarding the plant height, biomass yield and seed yield of each variety, which is hopeful to fill the gap of low quantity feed. In addition to the nutritional values were promising particularly the crude protein (CP), Dry matter (DM) and Organic Matter (OM) content in Beresa-17 variety. Based on its adaptability, high biomass yield, high seed yield, good CP, DM and OM of Gais -55 is recommended for further promotion in the midland of East Guji zone.
\end{abstract}

Keywords: Lablab, Nutritive Value, Adola, Chemical Composition

\section{Introduction}

Ethiopia owns the largest livestock population among African countries [1], and has high potential in livestock genetic resources [2]. Livestock production is an important component of the farming systems in all parts of Ethiopia and plays a vital role in the livelihood of many people [3]. However, the productivity of livestock is below the African average due to inadequate supply of feed and poor feeding practice [4]. The amount of feed and its quality are the key determinant of the livestock sector in Ethiopia [5], as it affects animal production and productivity [6].

To combat the livestock feed shortage, the use of improved forage plants as a feed source is recommended [7]. This has limited the performance of animals [7]. Thus, the introduction of high yielding, drought, and disease tolerant and wide agro-ecology adapted forage is a way to enhance livestock production and productivity [8].

The performance and yield of the different forage species could be markedly different and is also influenced by area of origin, including temperature, light intensity, total rainfall, soil type, fertilization level, and stage of maturity at harvest [9].

Leguminous forage can potentially be considered for use as a plant protein supplement to offset limitations associated with low feed quality in systems where livestock are 
increasingly becoming dependent on low quality roughages [10]. To improve the ever-increasing demand for animal products in developing countries like Ethiopia, options that enhance the supply of high quality livestock feed is a priority in feed resource development [11].

Lablab staying green during the dry season, it has been known to provide up to 6 tons of dry matter per hectare. Being palatable to livestock, it is adequate sources of much needed protein and can be utilized in several different ways [12]. Lablab purpureus varieties were among forage legume evaluated both on site and on farm level by Bore Agricultural Research Center to be used as alternative feed sources. It combines a great number of qualities that can be used successfully under varies conditions. However in Guji zone forage legumes was not evaluated and, As a result there were shortages of improved forage varieties for their livestock feeding purpose. Therefore, the present study was initiated with the objective to evaluate and select, recommend high quantity yielding and adaptable lablab varieties/accessions for the community.

\section{Materials and Method}

\subsection{Description of the Study Area}

The experiment was carried out at Adola sub-site of Bore Agricultural Research Center, Adola district, Guji Zone of Oromia. Adola district is located around at a distance of 470 $\mathrm{km}$ from Addis Ababa and $120 \mathrm{Km}$ from the zonal capital city, Negele Borena. It is an area where a mixed farming and sami-nomadic economic activity takes place, which is the major livelihood of the local people. The total area of the district is $1254.56 \mathrm{~km}^{2}$. The district is situated at $5^{\circ} 44^{\prime} 10^{\prime \prime}$ $6^{\circ} 12^{\prime} 38^{\prime \prime} \mathrm{N}$ latitudes and $38^{\circ} 45^{\prime} 10^{\prime \prime}$ - 39 $9^{\circ} 12^{\prime} 37^{\prime \prime}$ E longitudes. The district is characterized by three agro- climatic zones, namely highland $11 \%$, mid-land $29 \%$ and low-land $60 \%$ respectively. The major soil type of the district is nitosols (red basaltic soils) and orthic Acrosols [13].

\subsection{Experimental Treatments and Design}

The study was executed using Beresa-17, Gabis-55 and local varieties. The experiment was conducted in randomized complete block design with three replications. Seeds were sown in rows at spacing of $30 \mathrm{~cm}$ with seed rate of $30 \mathrm{~kg} \mathrm{ha}^{-}$ ${ }^{1}$. Plot size of $1.8 \mathrm{~m} \mathrm{x} 3$ was used. NPS fertilizer at $100 \mathrm{~kg} \mathrm{ha}^{-}$ ${ }^{1}$ was uniformly applied for all treatments at sowing time.

\subsection{Data Collection}

All relevant datas including days to flowering, days to forage harvest (maturity), plant height, logging $\%$, forage dry matter yield, seed yield and nutritive value were collected. Seed yield weight was calculated at $10 \%$ moisture content. At $50 \%$ flowering stage the middle rows of each plot were harvested for dry matter herbage determination and chemical analysis. Plants were harvested at ground level and fresh biomass weighed immediately using a $0.1 \mathrm{~g}$ scale. Then, a sub-sample of $15-20 \%$ of the total weight was separated and put into a paper bag for dry matter herbage determination. The samples were oven dried at $105^{\circ} \mathrm{C}$ for 24 hours. To determine grain yield, the pods were harvested from the rest rows at optimum physiological maturity by hand picking.

\subsection{Statistical Analysis}

All collected data were analyzed using general linear model procedure SAS [14], version 9.1. Means were separated with least significant difference (LSD) at 5\% significant level. The statistical model for the analysis data was: $\mathrm{Y}_{\mathrm{ijk}}=\mu+\mathrm{A}_{\mathrm{j}}+\mathrm{B}_{\mathrm{i}}+\mathrm{e}_{\mathrm{ijk}}$

Where; $Y_{\mathrm{ijk}}=$ response of variable under examination, $\mu=$ overall mean, $A_{j}=$ the $j$ th factor effect of treatment/ cultivar, $\mathrm{B}_{\mathrm{i}}=$ the ith factor effect of block/ replication, $\mathrm{e}_{\mathrm{ijk}}=$ the random error.

\section{Results and Discussion}

\subsection{Yield and Yield Components}

Mean value of all agronomic and yield parameters of lablab varieties are shown in (table 1). The results showed that days to $50 \%$ flowering, plant height, pod per plant, pod length per plant, fresh biomass yield and seed yield were not significantly $(p>0.05)$ differ between treatments. However, numerically Gabis-55 variety showed higher biomass yield, whereas Beresa-17 variety produced the maximum seed yield. The local variety took longer days (86.6 days) to reach $50 \%$ flowering while beresa-17 and gabis-55 reached 50\% flowering at 83.1. The highest plant height was measured from Gabis-55 variety $(138 \mathrm{~cm})$ followed by Beresa-17 $(126.6 \mathrm{~cm})$ while, the shortest plant height was obtained from genotype local $(112.8 \mathrm{~cm})$. The mean value observed in plant height of lablab varieties in the current study in the study area was $1.258 \mathrm{~cm}$. However, lower than the value that observed by Denbela and Worikicha [15] reported $02.1 \mathrm{~cm}$. The highest biomass yield $6.54 \mathrm{t} /$ ha was recorded from of Gabisa-55 variety followed by local variety $5.16 \mathrm{t} /$ ha while the lowest biomass yield of $4.22 \mathrm{t} / \mathrm{ha}$ was obtained from Beresa-17 variety. The Mean biomass yields of the tested varieties in the study area were $5.309 \mathrm{t} / \mathrm{ha}^{-1}$, which was highly different from the result of Denbela and Worikicha [15] reported $39.32 \mathrm{t} / \mathrm{ha}^{-1}$. The variability might be related to differences in geographical location, sowing time and soil type. However significant $(\mathrm{p}<0.05)$ different to date of maturity was observed between treatments. The local variety was early maturing (129.2 days) and followed by Beresa-17 (131 days) whereas, the late to seed maturing variety was Gabis-55 (144 days).

\subsection{Chemical Composition}

The analysis of chemical composition indicated that DM, $\mathrm{CP}, \mathrm{NDF}, \mathrm{ADL}, \mathrm{ADF}, \mathrm{TASH}$ and $\mathrm{OM}$ was not significantly $(\mathrm{P}>0.05)$ different between treatments. Numerically Beresa17 variety was highest in $\mathrm{OM}, \mathrm{CP}, \mathrm{NDF}$ and DM and less in $\mathrm{ADF}, \mathrm{ADL}$, and TASH content, Gabis-55 was highest in ADL and $\mathrm{ADF}$ and less in $\mathrm{CP}$ content were as, the local variety had 
the highest in NDF and TASH and less in DM content than the rest accessions. As herbaceous forage legume, Lablab purpureus forage has an average protein content of about $18 \%$ of DM, which varies from 13 to $24 \%$ depending on local conditions and stage of harvest [16]. In the current study average crude protein of Beresa-17 was $28.7 \%$ which was not agreed with the reported by Abuye Tullu [16]. This difference might be occurred due to season of sowing the crops and harvesting interval of the variety.

Table 1. Yield and yield components of Lablab varieties.

\begin{tabular}{|c|c|c|c|c|c|c|c|}
\hline Varieties & D50\%F & DM & Ppp & Pol (cm) & $\mathrm{Ph}(\mathrm{cm})$ & FBMY (t/ha) & GY qt /ha \\
\hline Gabis-55 & 85.3 & $144 a$ & 15.7 & 3.7 & 138 & 6.54 & 29.3 \\
\hline Baresa-17 & 83.1 & $131 \mathrm{~b}$ & 22.1 & 2.3 & 126.6 & 4.22 & 33.9 \\
\hline Local & 86.6 & $129.2 b$ & 13.2 & 3.3 & 112.8 & 5.16 & 14.4 \\
\hline Mean & 85 & 134.7 & 17 & 3.08 & 125.8 & 5.309 & 25.8 \\
\hline $\mathrm{CV}$ & 5.8 & 8.7 & 65 & 52.9 & 21.05 & 59.6 & 182.6 \\
\hline $\operatorname{LSD}(5 \%)$ & ns & $*$ & ns & ns & ns & ns & $\mathrm{ns}$ \\
\hline
\end{tabular}

${ }^{\mathrm{a}, \mathrm{b}}$ Mean in a column within the same category having different superscripts differ significantly at ( $\mathrm{p}<0.05$ ) $\mathrm{D} 50 \% \mathrm{~F}=$ days to $50 \%$ lowering, $\mathrm{DM}=\mathrm{Maturity}$ date, $\mathrm{Ppp}=$ Pod per plant, $\mathrm{Pol}=$ Pod length centimeter, $\mathrm{Ph}=$ plant height centimeter, $\mathrm{FBMY}=$ fresh biomass yield tone per hectare, $\mathrm{GY}=$ grain yield, $\mathrm{Cv}=\mathrm{Coefficient}$ of variation, $\mathrm{LSD}=$ Least significant difference. $\mathrm{ns}=$ Non significant ${ }^{*}=$ significant

Table 2. Mean chemical composition of lablab varieties.

\begin{tabular}{|c|c|c|c|c|c|c|c|}
\hline Varieties & DM\% & СР\% & NDF\% & ADL\% & ADF\% & TASH\% & OM\% \\
\hline Beresa-17 & 89.9 & 28.7 & 65.2 & 8.4 & 33.6 & 11.7 & 78.3 \\
\hline Gabis-55 & 89.4 & 20.4 & 68.2 & 13.7 & 37.7 & 12.1 & 77.3 \\
\hline Local & 88.3 & 26.5 & 76.8 & 10 & 35.6 & 14.4 & 73.9 \\
\hline
\end{tabular}

$\mathrm{ADF}=$ Acid Detergent Fiber; ADL = Acid Detergent Lignin; $\mathrm{CP}=$ Crude Protein; NDF = Neutral Detergent Fiber and OM = Organic Matter; TASH=Total Ash; $\mathrm{DM}=$ Dry matter.

\section{Conclusions and Recommendation}

The results revealed that Gabis -55 was well adapted and being productive by traits like; plant height, biomass yield and seed yield. The nutritional values (chemical composition) were promising particularly the crude protein (CP), Dry matter (DM) and Organic Matter (OM) content in Gais -55 variety. Therefore it could be possible to conclude that the Lablab varieties especially Beresa-17 used as a quality of protein supplement for midland of Guji which are affecting from less quality roughage and less palatable crop residues which are the major animal feed sources particularly in Guji. Based on its yield and performances Gabis-55 is recommended for further promotion in the midland of Guji zone and similar agro-ecologies. Further research is needed to exploit its potential under a range of livestock production performances.

\section{Acknowledgements}

The authors are grateful to the Oromia Agricultural Research Institute (IQQO) for financial support to implement the study. The animal nutrition laboratory workers of Haramaya University were also acknowledged for their support in the chemical analysis of the feed samples.

\section{References}

[1] CSA (Central Statistical Agency) (2017). Agricultural sample survey. Volume II: Report on livestock and livestock characteristics (Private peasant holdings). Statistical Bulletin 585: Central Statistical Agency (CSA), Federal Democratic
Republic of Ethiopia, Addis Ababa.

[2] Teweldemedhn M., 2018. Characterization of productive and reproductive performances, morphometric and challenges and opportunities of indigenous cattle breeds of Ethiopia: A review. International Journal of Livestock Production. 9 (3): 29-41. DOI: 10.5897/IJLP2017.042.

[3] Tekliye L., Mekuriaw Y., Asmare B., Mehret F., 2018. Nutrient intake, digestibility, growth performance and carcass characteristics of Farta sheep fed urea-treated rice straw supplemented with graded levels of dried Sesbania sesban leaves. Agric \& Food Secur, 7: 0226-9.

[4] Gelayenew B., Nurfeta A., Assefa G., Asebe, G., 2016. Assessment of Livestock Feed Resources in the Farming Systems of Mixed and Shifting Cultivation, Gambella Regional State, Southwestern Ethiopia. Global Journal of Science Frontier Research (D), 16: 5-1.

[5] ACDI/VOCA, 2017 at www.acdivoca.org.

[6] FAO, 2016. Ethiopia Climate-Smart Agriculture Scoping Study, by Jirata M., Grey S. and Kilawe E. Addis Ababa, Ethiopia (www.fao.org/publications).

[7] Malede, B., 2013. Role of Seeding Rates and Cutting Stages on Yield and Quality of Forage Intercropping in the Case of North Gondar. Ethiopia, LAP, LAMBERT Academic Publishing, Germany, ISBN: 978-3-659-25690-5-1.

[8] Shapiro, B., Gebru, G., Desta, S., Negassa, A., Nigussie, K., Aboset, G., Mechal, H., 2015. Ethiopia Livestock Master Plan. ILRI Project Report. International Livestock Research Institute (ILRI), Nairobi, Kenya.

[9] Jančík F., Koukolová V., Kubelková P., Čermák B., 2009. Effects of grass species on ruminal degradability of silages and prediction of dry matter effective degradability. Czech J Anim Sci.; 54: 315-23. 
[10] Umuna N. N., Osuji P. O., Nsahlai I. V., Khalili H. \& Mohamed-Saleem M. (1995). Effects of supplementing oat hay with Lablab, Sesbania, and Tagasaste or wheat middlings on voluntary intake, utilization and weight gain of Ethiopian Menz sheep. Small Ruminant Research. 18: 113-120.

[11] Getnet Assefa. 2007. Evaluation of Tagasaste (Chamaecytisus palmensis) as forage for ruminants. Humboldt University of Berlin, PhD dissertation, Report 75-100, Germany.

[12] Murphy A. M. \& Colucci P. E. (1999). A tropical forage solution to poor quality diets: A review of Lablab purpureus. Livestock Res. Rural Dev. 11 (2): 96-113.

[13] Yazachew E, Kasahun D (2011). The National regional government of Oromia, Physical and socio economic profile of Guji zone districts. Bureau of Finance and Economic Development. The National Regional Government of Oromia, Addis Abeba.

[14] SAS, 2002. (9.2 version). SAS Users' guide, Statistical Analysis System (SAS) Institute, Inc, Cary, NC. Cary.

[15] Denbela H \& Worikicha H (2015). This is a research/review paper, distributed under the terms of the Creative Commons Attribution-Noncommercial $3.0 \quad$ Unported License http://creativecommons.org/licenses/by-nc/3.0/).

[16] Abuye Tullu (2017), thesis submitted to the school of animal and range science, postgraduate program directorate. 